\title{
Sultan Agung Hanyakrakusuma dan Eksistensi Kesultanan Mataram
}

\author{
Agus Susilo, Yeni Asmara \\ Agussusilo594@yahoo.co.id \\ STKIP PGRI Lubuklinggau
}

\begin{abstract}
The purpose of writing this scientific paper is to find out the struggle of Sultan Agung Hanyakrakusuma Senopati ing Ngalaga Ngadurrahman in maintaining the existence of the Mataram Kingdom in 1613 AD $1646 \mathrm{M}$. The method in this study is the historical research method. In the historical research method, the researcher follows the steps such as Heuristics, Source Verification or Source Criticism (External Criticism and Internal Criticism), Interpretation, and Historiography. The results of this study, such as: 1) Policy and Glory of Sultan Agung Hanyakrakusuma Senopati ing Ngalaga Ngadurrahman (1613-1646 AD). At that time the Sultanate of Mataram Islam underwent a glory in the days of the leadership of Sultan Agung Hanyakrakusuma, the Sultanate of Mataram had actively expanded its territory to almost the entire island of Java and was highly respected for the Kingdoms or other nations. Religious life, where Islam became the largest religion in the Sultanate of Mataram, socio-economic, cultural and political development is very rapid. 2) Sultan Agung Hanyakrakusuma Senopati ing Ngalaga Ngadurrahman (1613-1646 AD) Against the VOC in Batavia and Ended in Power, namely as many as 3 times Sultan Agung Hanyakrakusuma expanded to Batavia at the VOC headquarters (the Netherlands). The conclusion of this research is the struggle of Sultan Agung Hanyakrakusuma Senopati ing Ngalaga Ngadurrahman in maintaining the existence of the Mataram Kingdom in 1613 AD - 1646 AD is very large. Sultan Agung Hanyakrakusuma has the ambition of uniting the entire island of Java under the Sultanate of Islamic Mataram. What disturbed him at that time was the presence of foreign powers, namely the VOC in Batavia. So several attacks were carried out by Sultan Agung Hanyakrajusuma on the VOC in Batavia.
\end{abstract}

Keywords: Sultan Agung Hanyakrakusuma, Sultanate of Mataram, Eksistensi

\section{Abstrak}

Tujuan penulisan karya ilmiah ini adalah untuk mengetahui perjuangan Sultan Agung Hanyakrakusuma Senopati ing Ngalaga Ngadurrahman dalam menjaga eksistensi Kerajaan Mataram tahun 1613 M - 1646 M. Metode dalam penelitian ini adalah metode penelitian sejarah. Dalam metode penelitian sejarah, peneliti mengikuti langkah-langkahnya seperti Heuristik, Verifikasi Sumber atau Kritik Sumber (Kritik Ekstern dan Kritik Intern), Interpretasi, dan Historiografi. Hasil penelitian ini, seperti: 1) Kebijakan dan Kejayaan Sultan Agung Hanyakrakusuma Senopati ing Ngalaga Ngadurrahman (1613-1646 M). Pada masa itu Kesultanan Mataram Islam mengalami masa kejayaan dimasa kepemimpinan Sultan Agung Hanyakrakusuma, Kesultanan Mataram telah aktif memperluas wilayahnya hampir seluruh pulau Jawa dan sangat disegani bagi Kerajaan-Kerajaan atau bangsa lainnya. Kehidupan beragama, dimana agama Islam menjadi agama terbesar di Kesultanan Mataram, sosial ekonomi, budaya dan politik sangat pesat perkembangannya. 2) Sultan Agung Hanyakrakusuma Senopati ing Ngalaga Ngadurrahman (1613-1646 M) Melawan VOC di Batavia dan Berakhir Kekuasaannya, yaitu sebanyak 3 kali Sultan Agung Hanyakrakusuma melakukan ekspansi ke Batavia markas VOC (Belanda). Simpulan dari penelitian ini adalah Perjuangan Sultan Agung Hanyakrakusuma Senopati ing Ngalaga Ngadurrahman dalam menjaga eksistensi Kerajaan Mataram tahun 1613 M - 1646 M sangat besar. Sultan Agung Hanyakrajusuma 
memiliki ambisi menyatukan seluruh pulau Jawa dibawah Kesultanan Mataram Islam. Hal yang mengganggunya saat itu adalah adanya kekuasaan asing yaitu VOC di Batavia. Maka dilakukan beberapa kali serangan oleh Sultan Agung Hanyakrajusuma terhadap VOC di Batavia.

Kata Kunci: Sultan Agung Hanyakrakusuma, Kesultanan Mataram, Eksistensi

(c) (7) (O) This work is licensed under the Creative Commons Attribution-ShareAlike 4.0

International License

\section{Pendahuluan}

Sejarah kerajaan Islam di Nusantara menghubungkan perdagangan strategis di kawasan Asia Tenggara. Ketika agama Islam lahir di Timur Tengah (Arab) dengan cepat berkembang diberbagai kawasan termasuk Asia. Penyebar agama Islam dari berbagai status sosial termasuk para pedagang. Para pedagang dari Arab, Persia dan Gujarat (India) juga turut meramaikan perdagangan di Selat Malaka. Pada akhirnya, kerajaan-kerajaan tradisional di Nusantara baik bercorak Hindu-Budha atau Islam, memberi berbagai pengaruh terhadap munculnya birokrasi di Indonesia. Birokrasi tradisional di Jawa merupakan birokasi yang mendapat percampuran dari aspek lokal (Indonesia), Hindu-Budha dan Islam. Birokrasi tradisional di Jawa merupakan hal yang menarik untuk dibahas karena birokrasi di Jawa pada akhirnya mempengaruhi sebuah sistem sosiopolitik pemerintahan Indonesia, karena mayoritas rakyat Indonesia merupakan etnis Jawa dan pada umumnya birokrasi pemerintahan Indonesia, sejak masa kolonial sampai sekarang, tetap didominasi oleh orang-orang Jawa (Setianto, 2010)

Pada tahun 1560, kekuasaan Demak beralih ke Kerajaan Pajang yang didirikan oleh Jaka Tingkir/Hadiwijaya. Kerajaan Pajang terus mengadakan ekspansi ke Jawa Timur dan juga terlibat konflik keluarga dengan Arya Penangsang dari Kadipaten Jipang Panolan. Setelah berhasil menaklukkan Aryo Penangsang, Sultan Hadiwijaya raja Pajang (1550-1582), memberikan hadiah kepada Ki Ageng Penjawi dan Ki Ageng Pemanahan yang dianggap berjasa dalam penaklukan, Arya Penangsang. Ki Ageng Pemanahan dan Ki Penjawi. Ki Ageng Pemanahan memperoleh tanah di Hutan Mentaok dan Ki Penjawi memperoleh tanah di Pati. Ki Ageng Pemanahan 1558-1575 berhasil membangun Hutan Mentaok itu menjadi desa yang makmur, bahkan lama-kelamaan menjadi kerajaan kecil dan pusat pemerintahan berada di Mentaok, wilayah yang terletak di sebelah Timur Kota Yogyakarta Kotagede. Raja-raja Mataram Islam sadar akan tugasnya memasukkan unsur-unsur Islam dalam budaya Jawa dan mereka pun menyatakan legitimasi mereka juga sebagai raja-raja Islam dengan memakai gelar keagamaan Islam. Struktur kerajaan Mataram-Islam dalam pengembangan Islam dengan mendirikan Mahkamah Agung Islam dan ulama mendapat tempat sebagai Abdi dalem dalam urusan keagamaan, yang dikepalai oleh Penghulu. Selain itu Sultan Agung juga memberikan tanah perdikan kepada kaum ulama (kyai) yang mengasuh pondok pesantren, dalam rangka pengembangan Islam di tanah Mataram (Sungaidi, 2018; Zamzami, 2018). 
Agus Susilo, Yeni Asmara

Sultan Agung Hanyakrakusuma dan Eksistensi Kesultanan Mataram

Sebelum tahun 1000 telah berkembang suatu peradaban yang tinggi yang ditinggalkan oleh Kerajaan Mataram Hindu, yang wilayahnya meliputi Jawa Tengah bagian selatan. Peninggalan candi Hindu dan Budha tampak terdapat di daerah Kedu dan Mataram. Pusat pemerintahan Mataram Kuno itu menempati dataran rendah Sorogedug di sebelah timur Kota Yogyakarta sekarang. Di sana terdapat peninggalan kompleks candi Prambanan dan Kalasan. Sampai sekarang belum mendapatkan data-data yang dapat menghubungkan Mataram Islam yang berdiri akhir abad XVI itu dengan Mataram Kuno yang bukti-bukti kebesarannya masih dapat disaksikan sampai sekarang. Sultan pertama Kerajaan Mataram Islam adalah Panembahan Senopati merupakan kakek dari Sultan Agung, sering dipanggil juga Senopati Ing Alaga. Panembahan Senopati merupakan putra Ki Ageng Pamanahan, Ki Ageng Pamanahan itu sendiri adalah teman karib Sultan Adiwijaya (Raja Pajang). Ki Ageng Pamanahan, Sultan Adiwijaya, serta Ki Juru Martani adalah murid kesayangan dari Sunan Kalijaga. Ketiganya seperti saudara, sehingga tidak mengherankan jika Senopati, putra Ki Ageng Pamanahan oleh Sultan Adiwijaya dijadikan anak angkat (Ansari, 2010; Dalminto, 2014).

Mataram merupakan daerah yang subur, terletak antara Kali Opak dan Kali Praga yang mengalir ke Samudera Hindia, serta memberikan kemungkinan pertumbuhan dan perkembangan pusat kerajaan Mataram. Berdirinya Kerajaan Mataram Islam tidak terlepas dari sosok Ki Ageng Pemanahan yang turut berjasa mengalahkan Arya Penangsang dalam sebuah sayembara yang diadakan oleh Sultan Hadiwijaya dari Pajang.1 Ki Ageng Pemanahan selanjutnya memperoleh hadiah sayembara berupa Alas Mentaok (Mataram). Ki Ageng Pemanahan mulai berkerja keras membuka Alas Mentaok untuk dijadikan wilayah pemukiman yang tertata. Setelah berkuasa kurang lebih selama 7 tahun (1578-1584 M), Ki Ageng Pemanahan menyebut dirinya sebagai Ki Gede Mataram. Hal ini sekaligus sebagai bukti kesetiaanya pada Pajang. Ki Gede Mataram wafat pada tahun 1584 M, tahta Mataram selanjutnya digantikan oleh Danang Sutawijaya (anaknya) (Ansari, 2010; Santoso, 2016).

Kerajaan Mataram bermula dari tanah perdikan yang diberikan oleh Sultan Adiwijaya dari Kesultanan Pajang terhadap Ki Pemanahan sebagai balas jasa karena telah membantu Sultan Pajang untuk menghadapi perlawanan Arya Penangsang dari Jipang. Tanah perdikan yang diberikan Sultan Adiwijaya kepada Ki Pemanahan masih hutan yang dikenal dengan alas mentaok. Kurang lebih tujuh tahun Ki Pemanahan membangun Mataram yang menjadikan Mataram sebagai pusat kekuasaan yang baru yang diberi nama Kota Gede. Setelah Ki Pemanahan membangun Mataram kemudian ia menamakan dirinya sebagai Ki Ageng Mataram, meskipun Mataram masih dibawah kekuasan Kesultanan Pajang. Kemudian lambat laun Mataram berkembang menjadi kerajaan yang melebihi Kesultanan Pajang pada masa Panembahan Senapati.

Kerajaan Mataram yang tumbuh dan berkembang dari kerajaan patrimonial menjadi kerajaan feodal telah mengubah komposisi dan cara pengerahan tenaga birokrasi yang diperlukan. Panembahan Senopati sebagai pendiri awal Kerajaan Mataram menjalankan 
pemerintahan negara yang monarkal, sehingga dalam pemerintahnya tidak banyak memerlukan bantuan orang-orang atau tenaga lain bagi penyelenggaraan pemerintahan, keamanan, pertahanan, hukum, perdagangan, penarikan upeti dan keperluan lain. Kedudukan raja di dalam masyarakat seperti halnya kerajaan dikenal dengan istilah raja yang berkedudukan sebagai Kepala Negara. Dianggap keturunan atau penjelmaan dewa. Raja dianggap sebagai pemberi tuntunan baik dan mendatangkan keselamatan, kesejahteraan dan kemakmuran rakyat. Sebagai Kepala Negara, seorang raja mempunyai wewenang yang tidak terbantahkan dan tak dapat diganggu gugat dan juga berhak menetapkan kebijaksanaan yang dilaksanakan oleh aparat kerajaan dan rakyatnya (Sudjak, 2016; Zamzami, 2018).

Pada raja kerajaan mataram ketiga yakni Sultan Agung, tercatat melakukan beberapa kali perubahan atau penambahan gelar, seperti gelar "panembahan" yang dipakai pada awal pemerintahanya. Kemudian "Susuhunan" atau "Sunan" pasca keberhasilan dirinya menguasi Madura atau daerah-daerah para wali-wali besar Islam, dan gelar "Sultan" pada saat raja Banten menerima gelar Sultan dari pemuka Mekkah". Sultan Agung lahir pada Tahun 1593 di Kota Gede, Kerajaan Mataram dan wafat pada Tahun 1645 di Karta (Plered, Bantul), kerajaan Mataram. Nama asli Sultan Agung yakni Raden Mas Jatmika atau yang dikenal dengan sebutan Raden Mas Rangsang putra dari pasangan Prabu Hanyokrowati (raja kedua Mataram) dan Ratu Mas Adi Dyah Banowati (putri pangeran Benawa, raja Pajang).

Gelar bagi masyarakat Jawa memilki efek sosial yang kuat terhadap martabat seseorang. Penggunaan gelar bagi raja-raja Mataram merupakan salah satu upaya memperkokoh kekuasaan. Dalam masa kepemimpinan Sultan Agung, tercatat beliau melakukan perubahan gelar, mulai dari "Panembahan" menjadi "Susuhunan" atau "Sunan", hingga "Sultan" atau lengkapnya "Sultan Agung Hanyakrakusumo Sayyidin Panatagama Senopati Ing Alaga Abdurrahman Khalifatullah" sebagai upaya memperteguh kedudukannya sebagai raja yang besar. Perubahan gelar yang dipakai oleh Sultan Agung merupakan simbol yang memiliki makna. Kondisi dan situasi suhu politik pada saat itu sedang sangat tinggi. Seorang pemimpin harus mampu memutar otak untuk mencari berbagai strategi yang jitu agar dapat mempertahankan serta memperluas daerah kekuasaannya. Kerajaan Mataram mencapai puncak kejayaannya pada masa raja ketiga yang dipimpin oleh Sultan Agung. Kecerdasan Sultan Agung dalam menjalankan pemerintahannya tidak terlepas dari kecermatan dan kemampuan Sultan Agung dalam memahami situasi dan kondisi psikologis serta sosiologis rakyatnya (Hariyanto, 2019). Pada penelitian ini ingin menceritakan bahwa peran seorang pemimpin sangat penting dan selalu mendapat tantangan dari lawannya. Sebagai seorang yang memahami sejarah, permasalah internal seharusnya di hindari sehingga tidak terjadi korban di dalam internal dan tempat bekerja masing-masing. 
Agus Susilo, Yeni Asmara

Sultan Agung Hanyakrakusuma dan Eksistensi Kesultanan Mataram

\section{Metode}

Setiap orang dewasa yang normal mengetahui, telah membaca, dan telah menulis cukup sejarah untuk menemukan ilustrasi yang sesuai mengenai sebagian besar masalah yang ada dalam penulisan sejarah. Selama pengalaman itu ia telah membaca dan mendengar banyak dokumen sejarah, diantaranya surat kabar, surat-surat, dokumen resmi, dokumen hukum, pengumuman radio, pidato-pidato politik, statistikresmi, iklan, dan percakapan biasa. Dengan demikian cara menulis sejarah mengenai sesuatu tempat, periode, seperangkat peristiwa, lembaga atau orang, bertumpu kepada empat kegiatan pokok, yaitu:

1. Pengumpulan obyek yang berasal dari zaman tersebut dan pengumpulan bahan-bahan tercetak, tertulis, dan lisan yang boleh jadi relevan; Dalam pengumpulan obyek ini, peneliti berusaha mengumpulkan data dari artikel ilmiah, dan buku referensi yang relevan dengan kajian penelitian sejarah.

2. Menyingkirkan bahan-bahan (atau bagian-bagian dari padanya) yang tidak autektik; Selama mengumpulkan sumber yang terkait penelitian, peneliti melakukan seleksi data terhadap sumber yang akan menjadi rujukan dalam penelitian. Seleksi sumber data ini dilakukan pada kritik sumber.

3. Menyimpulkan kesaksian yang dapat dipercaya mengenai bahan-bahan yang autektik; Sumber-sumber yang menjadi kajian dalam penelitian yang digunakan benar-benar relevan dan dapat dipertanggung jawabkan. Sumber-sumber tersebut berasal dari sumber yang jelas dan mudah untuk ditelusuri.

4. Penyusunan kesaksian yang dapat dipercaya itu menjadi sesuatu kisah atau penyajian yang berarti

5. Dalam penelitian ini, peneliti menulis sejarah berdasarkan kajian sumber yang jelas dan menyusunnya agar menjadi kajian sejarah yang obyektif (Gottschalk, 2010).

Metode membentuk mata rantai yang paling penting di dalam rantai belajar mengajar, yang di satu sisi mempunyai tujuan dan sasaran, dan disisi lain mempunyai hasil dan nilai (Kochar, 2010; Ayatullah Muhammad Al Fath, 2015). Metode adalah mata rantai tengah yang menghubungkan tujuan dengan hasil atau nilai metode tersebut. Metode yang menentukan kualitas sebuah hasil. Dalam penelitian sejarah sendiri mengenal beberapa langkah-langkah penulisan penelitian dengan metode penelitian sejarah, yaitu: Heuristik adalah teknik awal dalam penelitian sejarah. Heuristk ini merupakan langkah bagaimana peneliti menemukan sumber baik dalam melalui kajian kepustakaan, studi pengamatan, maupun melalui wawancara tokoh sejarah terkait penelitian. Verifikasi Sumber (Kritik Sumber) adalah teknik dimana setelah didapatkan sumber-sumber terkait penelitian harus melalui penilaian atau kritik sumber apakah sumber tersebut valid untuk dijadikan bahan penelitian atau tidak. Dalam verifikasi sumber ini ada dua teknik kritik sumber yang harus dilalui yaitu kritik ekstern dan kritik intern. Kritik ekstern adalah bagaimana peneliti menilai dengan jelas apakah sumber yang digunakan merupakan sumber yang harus dipakai, keasliannya apakah dapat dipertanggungjawabkan dan dapat disebut sebagai sumber yang akurat. Sedangkan kritik intern adalah bagaimana peneliti dapat menilai 
keakuratan dalam sumber yang didapatkan. Sejarah sebagai konstruksi sesungguhnya tidak pernah dimaksud sebagai potret, yaitu memuat secara lengkap segala sesuatu dari obyek yang difoto tersebut. Dalam penulisan sejarah juga tercakup pandangan, pendekatan, metode, dan gaya bahasa penulis sejarawan. Untuk merangkai sebuah fakta-fakta sejarah yang harus dilakukan dengan kemampuan berpikir logis (diskursif) dan memiliki imajinasi (Kartodirdjo, 1992; Rosana, 2014).

Interpretasi atau lebih dikenal dengan penafsiran, adalah dalam bagian ini, peneliti berusaha menafsirkan data-data penelitian yang telah didapatkan dari berbagai sumber penelitian. Hal yang terpenting dalam bagian ini, peneliti melakukan sintesis data-data atau sumber sejarah tentang Perjuangan Sultan Agung Hanyakusuma Dalam Menjaga Eksistensi Mataram yang didukung dengan teori-teori yang mendukung penelitian. Kemudian data-data penelitian tersebut disusunlah menjadi sebuah fakta penelitian ke dalam interpretasi yang baik. Setelah melalui sebuah penafsirah dari beberapa teori barulah kita membandingkan data yang ada dengan sumber-sumber terkait secara menyeluruh agar menjadi sebuah tulisan yang baik. Proses penulisan sejarah sebagai suatu penyusunan sintesis pembangunan yang untuk menjadikan sebuah bangunan. Perencanaan tulisan sejarah harus tertuang dalam suatu desain atau blueprint yang memuat lay out suatu tulisan yang akan dikembangkan. Untuk mencapai hasil sintesis pada dasarnya diperlukan suatu kerangka pikiran atau referensi yang mewadahi atau mencakup semua fakta yang tidak lagi dipersatukan sebagai agregasi atau hanya sebuah kumpulan, namun telah disusun berdasarkan hubungan-hubungan yang sesuai dengan desain (Kartodirdjo, 1992; Rosana, 2014).

\section{Hasil dan Pembahasan}

Kurnialoh (2015), Rahman \& Hidayah (2012), menyatakan Sultan Agung Hanyakrakusuma lahir pada tahun 1592 M, tepatnya tanggal 14 November hari Jum'at). Ketika dinobatkan menjadi raja dia telah berusia 20 tahun. Usia yang sangat kondusif untuk memimpin suatu pemerintahan yang sedang berkembang. Darah muda yang mengalir penuh semangat membawa Mataram menjadi kerajaan yang besar. Terlepas dari berbagai macam legitimasi yang diciptakan para pendahulunya, ia mampu membawa Mataram pada puncak kejayaan dengan sifatnya yang tegas dan disiplin. Kedisiplinannya terletak pada saat acara seba. Seba yaitu acara yang diadakan setiap hari Senin dan Kamis yang selalu diadakan di kraton untuk menghadapi raja. Seluruh bawahan raja diwajibkan hadir pada acara ini, dari yang berpangkat tumenggung sampai yang berpangkat rendah.

Dalam konsep kekuasaan Jawa, kekuasaan raja yang besar tetap harus diimbangi dengan kewajiban, ber budi bawa leksana, ambeg adil para marta , yaitu meluap budi luhur mulia dan sifat adil terhadap semua. Raja tetap harus menghukum yang bersalah meskipun anaknya sendiri yang melakukan kesalahan. Seorang raja mengambil istri orang lain asal diberi ganti rugi yang 


\section{Agus Susilo, Yeni Asmara}

Sultan Agung Hanyakrakusuma dan Eksistensi Kesultanan Mataram

sepadan. Begitu juga yang terjadi pada Sultan Agung Hanyakrakusuma, dengan orang-orang yang berjasa, sultan memberi ganjaran yang setimpal. Atas jasa Bupati Priangan menindas pemberontak Adipati Ukur di tahun 1630, sultan memberi kemurahan hati kepadanya untuk tidak hadir dalam pesewonan selama pitung pajenengan atau tujuh tahun. Tumenggung Wiragunan bahkan dibuatkan istana yang megah karena kesetiaannya pada Sultan. Hubungan antara raja dan rakyat juga menunjukkan adanya saling ketergantungan antara dua aspek yaitu pimpinan dan yang dipimpin. Adanya hubungan yang khas tersebut pada masa Mataram Islam merupakan wujud dari sinkritisme dengan mendapat unsur filosofis India. Dengan pemikiran imaginatif-proyektif, orang Jawa melambangkan kesatuan kawula-gusti dengan benda yaitu keris sebagai senjata kebesaran. Dua bagian keris sebagai simbol hubungan tersebut yaitu warangka (sarung) yang disamakan dengan rakyat, dan curiga (mata) yang digambarkan sebagai raja. Nilai keris diukur dengan kekuatan gaib yang dikenal sebagai pamor (tatahan besi meteorit pada matanya) dan diperoleh dari kekuatan magis sang pembuat yaitu empu.

Salah satu peran kepemimpinan yang harus dijalankan oleh seorang dijalankan dengan cara memberikan pujian dan dukungan. Pujian dapat diberikan dalam bentuk penghargaan dan insentif. Penghargaan adalah bentuk pujian yang tidak berbentuk uang, sementara insentif adalah pujian yang berbentuk uang atau benda yang dapat kuantifikasi. Peran membangkitkan semangat kerja dalam bentuk memberikan dukungan, bisa dilakukan melalui katakata, baik langsung maupun tidak langsung, dalam kalimat-kalimat yang sugestif. Sebagai orang yang berada di puncak dan dipandang memiliki pengetahuan yang lebih baik dibanding yang dipimpin, seorang pemimpin juga harus mampu memberikan bimbingan yang tepat dan simpatik kepada bawahannya yang mengalami masalah dalam melaksanakan pekerjaannya (Potu, 2013; A. Susilo \& Sarkowi, 2020).

Dalam pengesahan seseorang menjadi raja, pada umumnya juga menghadirkan tokoh agama untuk memperkuat legitimasi keagamaan. Cara pengesahan raja selain berdasar keturunan juga didasarkan pada kepercayaan adanya wahyu (persetujuan Tuhan berdasar firasat atau kejadian tertentu, dalam istilah Jawa sering dikatakan kan pulung). Cara pengesahan raja yang demikian sebagai upaya meningkatkan kewibawaan sang raja. Hal ini disebabkan, jika raja merupakan sumber kekuatan yang utama dan pokok, menyeluruh dan bersifat tunggal dalam negara, perhatian utamanya tentunya meningkatkan kewibawaan itu sendiri. Cara lain meningkatkan kewibawaan dan kemegahan raja adalah adanya silsilah raja. Semakin banyak tokoh-tokoh penting, nyata ataupun fiktif yang legendaris, menjadi bagian dari silsilah raja serta semakin panjang silsilah raja, maka hal ini berdampak positif terhadap martabat raja. Pada masa Jawa Islam tersebut, fungsi pusaka raja dan kerajaan juga memperkuat posisi raja. Benda magis tersebut sebagai bagian dari alat untuk meningkatkan aura kerajaan (Setianto, 2010)

Para ulama yang ada di lingkungan Kerajaan Mataram Islam, selanjutnya oleh raja Mataram Islam diangkat menjadi penasihat dan pembimbingnya. Bersamaan dengan itu, adanya tokoh yang bernama Sunan Kalijaga dianggap sebagai yang berinisiatif membangun tembok 
keliling kerajaan bersama dengan Senapati Kediri.16 Pengaruh wali dan tokoh agama demikian kuat, sehingga segala nasihat dan restu mereka penting bagi seseorang yang akan menduduki tahta kekuasaan. Gerak Panembahan Senapati sebagai raja Kerajaan Mataram Islam tidak lepas dari bimbingan dan restu mereka, yaitu para wali dan kyai.17 Salah satu murid Sunan Ampel, wali yang berdiam di salah satu pusat penting Agama Islam, yaitu di Giri dekat Gresik, dan para penggantinya memainkan peran penting dalam meredakan ketegangan antara para raja Mataram dan para vasal mereka yang sangat berkuasa di daerah-daerah pantai Jawa Timur, yang dipimpin oleh Adipati Surabaya. Selanjutnya peran yang dilakukan pula oleh Sunan Kalijaga dan Sunan Kudus dari Jawa Tengah bagian utara, yang melibatkan persekongkolan di Kraton Demak ketika secara aktif menyokong Arya Penangsang atas tahta (Suryo, 2000; Zamzami, 2018).

Raden Mas Jolang mangkat pada tahun 1613 M. setelah wafatnya Raden Mas Jolang, Raden Mas Wuryah (Adipati Martapura) naik tahta sebagai Raja Mataram. Namun karena memiliki cacat grahita, Raden Mas Wuryah hanya menjabat sebagai Raja Mataram selama sehari. Tahta Mataram selanjutnya diduduki oleh Raden Mas Rangsang. Raden Mas Rangsang ini kemudian lebih kita kenal dengan nama Sultan Agung Hanyakrakusuma. Sultan Agung merupakan putra dari Raden Mas Jolang dengan Dyah Banowati. Sultan Agung memiliki dua permaisuri, yaitu Ratu Kulon yang merupakan putrid dari Sultan Cirebon dan Ratu Wetan yang merupakan putrid Tumenggung Upasanta dari Kadipaten Batang. Dari Ratu Kulon, Raden Mas Rangsang memiliki putra yang bernama Raden Mas Sahwawrat atau Pangeran Alit. Sementara dari Ratu Wetan, Raden Mas Rangsang memiliki putra bernama Raden Mas Sayidin (Arya Prabu Adi Mataram).

Di masa pemeritahan Sultan Agung Hanyakrakusuma, Mataram mengalami puncak kejayaan. Berkat kebijakan-kebijakan Sultan Agung, Mataram membangun Angkatan Perang yang sangat kuat. Berkat kebijakan-kebijakan Sultan Agung, Mataram juga mengalami perkembangan di bidang bahasa, kesusastraan, dan kebudayaan. Melalui kebijakannya, Sultan Agung Hanyakusuma menetapkan penggunaan Bahasa Bagongan untuk para bangsawan dan pejabat demi terciptanya rasa persatuan di antara penghuni istana. Sementara bahasa Sunda juga mengalami perubahan sejak Kerajaan Mataram menguasai Jawa Barat. Hal ini ditandai dengan terciptanya bahasa halus yang sebelumnya hanya dikenal di Jawa Tengah.

Melalui Sultan Agung Hanyakrakusuma, Kerajaan Mataram berupaya untuk mengembangkan dunia kesusastraan. Berkat kepiawaiannya di bidang sastra, Sultan Agung mengubah Serat Sastra Gendhing. Melalui Serat Sastra Gendhing, Sultan Agung Hanyakrakusuma mengajarkan mengenai filsafat hidup dan kepemimpinan Jawa. Sultan Agung menaruh perhatian besar terhadap kebudayaan di Kerajaan Mataram. Melalui Sultan Agung Hanyakrakusuma ini, Kalender Hijriyah yang dipakai di pesisir Utara dipadukan dengan Kalender Saka yang masih dipakai di pedalaman. Hasilnya adalah terciptanya Kalender Jawa Islam sebagai pemersatu rakyat Mataram (Achmad, 2016; Rahmaniar et al., 2020). 
Agus Susilo, Yeni Asmara

Sultan Agung Hanyakrakusuma dan Eksistensi Kesultanan Mataram

Setiap raja yang naik tahta pada kerajaan Mataram selalu dihadapi tantangan masalah pemantasan diri. Pemantasan diri dilakukan raja disebabkan adanya tekanan dari masyarakat sekitar yang masih belum dapat menerima kehadiran kerajaan Mataram. Hal tersebut dikarenakan kerajaan-kerajaan sebelumnya berasal dari keturunan para penguasa, sedangkan kerajaan Mataram hanya berasal dari keturunan petani (kalangan rendah) yang kala itu menjadi kasta terendah. Hal demikian menjadi tantangan dan tugas utama Sultan Agung untuk terlebih dahulu meyakinkan rakyat Mataram bahwa dirinya pantas menjadi Raja. Pasca keberhasilan menguasai Jawa Timur, Sultan Agung melanjutkan ekspansi ke Jawa Barat khususnya Banten. Banten merupakan jalur pelayaran dan perdagangan antara kerajaan di Indonesia dan sekitarnya. Bahkan dengan bangsa-bangsa dengan berbagai negeri di Asia dan Eropa bahkan di Asia bagian Timur. Hal ini menjadi daya tarik sendiri mengingat sebelumnya, Sultan Agung telah berhasil menguasai Jawa Timur (Surabaya), yang notabenya dijadikan sebagai jalur pelayaran Secara garis politik, seusai Sultan Agung menguasi Jawa Timur, maka gerakan dakwah (ekspansi wilayah) dilanjutkan kewilayah Jawa Barat, salah satunya Banten yang secara geografis juga sama dengan posisi Surabaya yang di pesisir. Banten menjadi kompetitor Pada tahun 1641, Sunan Agung berhasil mendapatkan gelar bernuansa Arab dari pemimpin ka'bah di mekkah yakni Sultan Abdullah Muhammad Maulana Mataram, sehingga Sultan Agung disebut sebagai Sultan Mataram. Gelar tersebut tidak dapat dimaknai sebatas sebutan semata, melainkan juga bagian dari legitimasi politik (Hariyanto, 2019).

Kemampuan atau kecakapan seorang pemimpin adalah sebagai tulang punggung masyarakat yang dipimpinnya. Sebagai seorang pemimpin yang mampu membuat perubahan, memajukan dan mendorong masyarakat yang dipimpinnya untuk mencapai kehidupan yang makmur dan sejahtera. Sebagai pemimpin harus mengembangkan budaya kepemimpinan yang dapat menjunjung visi misi wilayah yang dipimpinnya sesuai yang telah ditetapkan. Budaya kepemimpinan yang dimaksud adalah pola perilaku yang meliputi pemikiran, tindakan, bahasa dan kebiasaan yang dilakukan oleh anggota kepemimpinan, nilai-nilai yang dibagi atau dirasakan bersama oleh anggota suatu wilayah kepemimpinan untuk mengelola masalah dan pengaruh yang dapat terjadi. Kelangsungan kepemimpinan wilayah harus berdasarkan nilai-nilai yang fundamental dalam menjaga wilayah kekuasaannya dengan baik, seperti menjunjung tinggi kejujuran dan integritas serta tata kelola yang baik (Ikhwan, 2018; Y. I. \& A. Susilo, 2018).

Raden Mas Rangsang menjadi raja Mataram pada usia 20 tahun, dengan gelar Sultan Agung Hanyakrakusuma Senopati ing Ngalaga Ngadurrahman (1613-1646 M). Pada masa pemerintahannya, Kerajaan Mataram mengalami masa kejayaannya. Hal ini ditandai luasnya wilayah Kerajaan Mataram yang mencakup hampir seluruh Pulau Jawa, kecuali Batavia dan Banten, serta berbagai daerah di luar Jawa seperti Palembang di Sumatera dan Sukadana di Kalimantan. Sultan Agung juga menjalin hubungan diplomatik dengan Makasar, negeri terkuat di Sulawesi pada saat itu. Luasnya wilayah Kerajaan Mataram tidak terlepas dari politik ekspansi yang diterapkan oleh Sultan Agung. Pada masa pemerintahannya, Sultan Agung juga dikenal 
sebagai seorang budayawan dan ahli hukum. Sultan Agung pernah memiliki cita-cita untuk menyatukan Pulau Jawa di bawah Kerajaan Mataram (Munawar, 2020; Santoso, 2016).

Sultan Agung mencurahkan perhatiannya pada bidang ekonomi dan kebudayaan. Upayanya antara lain memindahkan penduduk Jawa Tengah ke Kerawang, Jawa Barat, di mana terdapat sawah dan ladang yang luas serta subur. Sultan Agung juga berusaha mengakulturasikan unsurunsur kebudayaan Indonesia asli dengan Hindu dan Islam. Misalnya Garebeg disesuaikan dengan hari Malulud Nabi Muhammad SAW, hari raya Idul Fitri dan hariraya Idul Adha. Sejak itu dikenal Garebeg Mulud, Garebeg Puasa dan Garebeg Besar.. Pembuatan tahun Jawa16 dan kitab filsafat Sastra Gendhing merupakan karya Sultan Agung yang lainnya. Pada masa Sultan Agung perdagangan semakin melemah, pelayaran dan pusat perdagangan pelabuhan menjadi mundur lantaran didominasi oleh Belanda. Pada tahun 16281629, Sultan Agung ingin menguasai Batavia, ia mengirim pasukan yang dipimpin oleh Baureksa dan dibantu oleh Adipati Ukur serta Suro Agul-Agul, namun usaha itu gagal (Munawar, 2020; Sungaidi, 2018).

Dengan kultus kemegahan ini, maka dapat ditafsirkan bahwa tujuan utama kedudukan raja di Jawa untuk mengejar kemuliaan dan praktik binanegara. Namun dalam perspektif citacita dan kosmologi, kedudukan raja Jawa sebagai cerminan pemerintahan Tuhan yang bertujuan mempertahankan keselarasan dan ketertiban dalam kehidupan. Hal ini berarti, raja tidak sematamata bercita-cita menumpuk kekayaan untuk kepentingannya endiri. Dalam tradisi Jawa, harta benda bukanlah sebagai tujuan hidup. Mereka cenderung mengganggap kebesaran atau agungnya seseorang atau raja dikarenakan kebesaran atau kesempurnaan batin. Mementingkan kekayaan atau bersikap materialistis dianggap sebagai sikap tercela. Tanda-tanda kebesaran raja juga diperhatikan oleh rakyatnya. Penyalahgunaan kekuasaan dianggap sebagai tanda bahwa kebesarannya menyusut sehingga keruntuhan segera datang (Palinggi \& Prayogyandarini, 2020; Setianto, 2010).

Setiap raja yang naik tahta pada kerajaan Mataram selalu dihadapi tantangan masalah pemantasan diri. Pemantasan diri dilakukan raja disebabkan adanya tekanan dari masyarakat sekitar yang masih belum dapat menerima kehadiran kerajaan Mataram. Hal tersebut dikarenakan kerajaan-kerajaan sebelumnya berasal dari keturunan para penguasa, sedangkan kerajaan Mataram hanya berasal dari keturunan petani (kalangan rendah) yang kala itu menjadi kasta terendah. Hal demikian menjadi tantangan dan tugas utama Sultan Agung untuk terlebih dahulu meyakinkan rakyat Mataram bahwa dirinya pantas menjadi Raja. Seiring perpindahan pusat kekuasaan Islam dari pesisir ke pedalaman dan surutnya peran para wali, perkembangan dakwah Islam ke pedalaman ternyata tidak mengalami penurunan, melainkan terus berkembang pesat. Dakwah Islam melalui jalur politik mencapai puncaknya pada masa Sultan Agung (16131645) (Hariyanto, 2019; Rosi, 2020).

Ekspansi yang dilaksanakan oleh Sultan Agung, juga ke arah barat Pulau Jawa. Seperti ke Sumedang, Sunda, Cirebon, Banten dan Batavia. Adapun kerajan Cirebon dan Sunda, telah 
Agus Susilo, Yeni Asmara

Sultan Agung Hanyakrakusuma dan Eksistensi Kesultanan Mataram

terlebih dahulu dengan sukarela menyerahkan diri kepada Mataram. Tiap tahun raja kecil yang menyerahkan diri akan melakukan perjalanan jauh dengan teratur ke Karta untuk mengantarkan upeti Karta. Selain dari penaklukkan beberapa daerah sebagaimana yang telah disebut diatas, Sultan Agung menyadari bahwa dengan hadirnya Kompeni Belanda di Batavia dapat membahayakan kesatuan negara yang dalam hal ini terutama meliputi pulau Jawa (Dalminto, 2014; Nurhayati \& Dwiadmojo, 2019).

Adanya angkatan perang yang sangat kuat bagi Kesultanan Islam, Sultan Agung mampu menaklukan berbagai wilayah di pulau Jawa sehingga wilayah kekuasaannya menjadi semakin sangat luas. Oleh karena ambisinya tersebut, Sultan Agung merencanakan untuk menyerang dan menguasai Batavia yang saat itu menjadi kekuasaan VOC Belanda serta menumpas berbagai pemberontakan yang dinilai membahayakan eksistensi Kesultanan Mataram. Melalui angkatan perangnya, Sultan Agung melakukan penyerangan terhadap VOC di Batavia yang menjadi penghalang niatnya untuk menaklukan Banten. Sejak perselisihan tersebut, Sultan Agung mengirim pasukan Mataram pertama di bawah komando Tumenggung Bahureksa (27 Agustus 1628 M) dan pasukan Mataram ke-2 di bawah kepemimpinan Pangeran Mandureja (Oktober 1628 M) ke Batavia untuk bertempur melawan VOC. Secara statistic ditotal jumlah pasukan Mataram tersebut mencapai sekitar 10.000 orang.

Perang besar antara Kesultanan Mataram melawan VOC berlangsung di Batavia (Holandia). Oleh karena kurang perbekalan, pasukan Mataram mengalami kekalahan. Sehingga Sultan Agung merencanakan serangan kedua yang dipimpin oleh Adipati Ukur (Mei, 1629 M) dan di bawah kepemimpinan Adipati Juminah (Juni, 1629 M). Total dari kedua pasukan Mataram tersebut mencapai \pm 14.000 orang. Kegagalan dalam serangan pertama yang dilakukan oleh pasukan Mataram melawan VOC tersebut diantisipasi dengan mendirikan lumbung-lumbung beras baik di daerah Karawang dan Cirebon. Namun VOC berhasil membakar lumbung-lumbung padi tersebut, sehingga serangan Pasukan Mataram yang kedua ini mengalami kegagalan. Meskipun mengalami kegagalan, Sultan Agung berhasil membendung dan mengotori Sungai Ciliwung, sehingga menimbulkan wabah kolera yang mampu membunuh banyak orang VOC termasuk Jenderal VOC yaitu J.P. Coen yang tewas karena penyakit tersebut. Tujuan Sultan Agung dalam mempersatukan pulau Jawa dianggap mengalami keberhasilan dan kejayaan, meskipun VOC dan Kesultanan Banten saat itu belum tunduk terhadap Kesultaan Mataram. Meskipun demikian Kesultanan Mataram Islam tetap dianggap mengalami kejayaan di masa kepemimpinan Sultan Agung Hanyakrakusuma.

\section{Simpulan}

Sultan Agung memiliki niat untuk menyatukan seluruh wilayah pulau Jawa dibawah panji Kesultanan Mataram. Niat tersebut berdasarkan bahwa Kesultanan Mataram Islam ingin menjadi sebuah negeri yang besar yang menjadi kiblat politik, ekonomi, sosial budaya dan agama 
Islam Kerajaan-Kerajaan di Nusantara. Sampai pada akhirnya cita-cita Sultan Agung tercapai, dimana dari Jawa Timur, Jawa Tengah dan sebagian wilayah Jawa Barat berada dalam kekuasaan Kesultanan Mataram Islam dibawah kepemimpinan Sultan Agung Sultan Agung Hanyakrakusuma Senopati ing Ngalaga Ngadurrahman. Ternyata keinginan Sultan Agung Hanyakrakusuma Senopati ing Ngalaga Ngadurrahman tidak hanya sampai disitu saja. Sultan Agung berniat untuk menguasai Kesultanan Banten yang saat itu dipimpin oleh Sultan Ageng Tirtayasa. Kesultanan Banten menarik bagi Kesultanan Mataram karena memiliki letak strategis dalam perdagangan luas. Namun langkah tersebut dinilai sangat sulit karena Kesultanan Banten sedang mengalami kejayaan. Adanya ancaman VOC di Batavia yang dinilai sangat berat jika harus melawan dua kekuatan besar. Maka Sultan Agung Hanyakrakusuma Senopati ing Ngalaga Ngadurrahman memerintahkan pasukannya untuk memerangi VOC di Batavia terlebih dahulu. Usaha Sultan Agung menyerang VOC di Batavia dilakukan sebanyak 3 kali. Perlawanan pertama mengalami kegagalan karena kurangnya swasembada makanan bagi pasukan Sultan Agung. Serangan kedua, pasukan mataram mengalami kegagalan karena strateginya diketahui oleh VOC dengan membakar lumbung pagi dibeberapa titik wilayah kekuasaan Mataram. Usaha penyerangan yang ketiga belum sempat dilakukan karena Sultan Agung Hanyakrakusuma Senopati ing Ngalaga Ngadurrahman wafat dan digantikan oleh Amangkutat I sebagai pemimpin Kesultanan Mataram Islam selanjutnya.

\section{Daftar Pustaka}

Achmad, S. W. (2016). Politik Dalam Sejarah Kerajaan Jawa Manuver E Intrik Politik Kerajaan-Kerajaan di Jawa dari Mataram Kuno Hingga Mataram Islam. Araska.

Al Fath, A. M. (2015). Penerapan Metode Inquiry Dalam Meningkatkan Motivasi Belajar IPA Materi Lingkungan Kelas V SD Negeri Kacangan I Kecamatan Sumberlawang. Visipena Journal, 6(2), 1-11.

Ansari, I. (2010). KEKUASAAN JAWA DALAM STRUKTUR KERAJAAN ISLAM AN PEWAYANGAN: SEBUAH ANALISIS STRUKTURALISME LEVI-STRAUS. Acintya Jurnal Penelitian Seni Budaya, 2(1).

Dalminto, D. (2014). STRATEGI SULTAN AGUNG DALAM EKSPANSI SERTA ISLAMISASI PADA KERAJAAN MATARAM ISLAM. UIN RADEN FATAH PALEMBANG.

Gottschalk, L. (2010). Mengerti Sejarah.(N. Notosusanto, Trans.). Yayasan Penerbit UI.

Hariyanto, H. (2019). GERAKAN DAKWAH SULTAN AGUNG (Arti Penting Perubahan Gelar Sultan Agung Terhadap Gerakan Dakwah di Jawa Pada Tahun 1613 M-1645 M). Jurnal AlBayan: Media Kajian Dan Pengembangan Ilmu Dakwah, 24(1).

Ikhwan, A. (2018). Sistem Kepemimpinan Islami: Instrumen Inti Pengambil Keputusan pada Lembaga Pendidikan Islam. Jurnal ISTAWA, 3(2). 
Agus Susilo, Yeni Asmara

Sultan Agung Hanyakrakusuma dan Eksistensi Kesultanan Mataram

Kartodirdjo, S. (1992). Pendekatan ilmu Sosial dalam Metodologi Sejarah. Gramedia Pustaka Utama.

Kochar, S. K. (2010). Pembelajaran Sejarah "Teaching of History". PT Gramedia Widiasarana Indonesia.

Kurnialoh, N. (2015). Nilai-Nilai Pendidikan Agama Islam Dalam Serat Sastra Gendhing. IBDA: Jurnal Kajian Islam Dan Budaya, 13(1), 98-113.

Munawar, Z. (2020). Pengelolaan Pajak di Kerajaan Mataram Islam MAsa Sultan Agung 16131645. Jurnal Peradaban Islam, 4((1)).

Nurhayati, E., \& Dwiadmojo, G. N. (2019). PETA PENAKLUKAN WILAYAH BAGIAN TIMUR PULAU JAWA OLEH BELANDA BERDASARKAN TEKS BABAD BASUKI. Diksi, 27(1), 17.

Palinggi, S., \& Prayogyandarini, P. M. (2020). Potensi Penyalahgunaan Wewenang Organisasi Kemasyarakatan (Ormas) Fiktif dalam Masyarakat Indonesia. Pamator Journal, 13(1), 74-80.

Potu, A. (2013). Kepemimpinan, motivasi, dan lingkungan kerja pengaruhnya terhadap kinerja karyawan pada Kanwil Ditjen Kekayaan Negara Suluttenggo dan Maluku Utara di Manado. Jurnal EMBA: Jurnal Riset Ekonomi, Manajemen, Bisnis Dan Akuntansi, 1(4).

Rahman, A. A., \& Hidayah, K. (2012). Islam dan Budaya Masyarakat Yogyakarta Ditinjau dari Perspektif Sejarah. EL HARAKAH (TERAKREDITASI), 13(1), 46-59.

Rahmaniar, F. S., Suyitno, S., Supana, S., \& Saddhono, K. (2020). Keselarasan Kearifan Lokal Dengan Nilai Keislaman Pada Tradisi Labuhan Gunung Kombang di Kabupaten Malang. Jurnal SMART (Studi Masyarakat, Religi, Dan Tradisi), 6(1), 113-125.

Rosana, L. N. (2014). Pengaruh Metode Pembelajaran dan Kemampuan Berpikir Kritis Terhadap Hasil Belajar Sejarah Siswa. Jurnal Pendidikan Sejarah, 3(1), 34-44.

Rosi, F. (2020). Gerakan Politik Kiai dan Dakwah Islam: Membaca Aktifitas Dahwah dan Politik Kiai pada Momentum Pemilu. Jurnal At-Turost, 7((2)).

Santoso, R. G. (2016). KEBIJAKAN POLITIK DAN SOSIAL-EKONOMI DI KERAJAAN MATARAM ISLAM PADA MASA PEMERINTAHAN AMANGKURAT I (1646-1677). Risalah, 1(2).

Setianto, Y. (2010). Birokrasi Tradisional di Jawa dalam Perspektif Sejarah. Paramita: Historical Studies Journal, 20(2).

Sudjak, S. (2016). Serat Sultan Agung: melacak jejak Islam Nusantara. CV. Bildung Nusantara.

Sungaidi, S. (2018). Dakwah: Priyayi dan Santrinisasi. Dakwah: Jurnal Kajian Dakwah Dan Kemasyarakatan, 22(2), 123-136.

Suryo, D. (2000). Tradisi Santri dalam Historiografi Jawa, Pengaruh Islam di Jawa. Seminar Pengaruh Islam Terhadap Budaya Jawa, Jakarta. 
DIAKRONIKA 20 (2) 2020 ISSN: 1411-1764 (Print) | 2620-9446 (Online)

Susilo, A., \& Sarkowi, S. (2020). Sejarah Surulangun Sebagai Ibukota Onder Afdeling Rawas Tahun 1901-1942. AGASTYA: JURNAL SEJARAH DAN PEMBELAJARANNYA, 10(1), 48-66.

Susilo, Y. I. \& A. (2018). Pangeran Asir dan Kepemimpinan Rupit Rawas. Harapan Cerdas.

Zamzami, R. (2018). Sejarah Agama Islam di Kerajaan Mataram pada Masa Penembahan Senapati (1584-1601). JUSPI (Jurnal Sejarah Peradaban Islam), 2(2), 17-28. 